\title{
Significant Reduction of Vitamin B12 Levels in Sudanese Sickle Cell Disease Patients
}

\author{
Ishraga Ibrahim Ahmed, Areig Mohamed Sir-Elfatouh, Nasr Eldeen Ali Mohammed Gaufri* \\ Department of Hematology, Faculty of Medical Laboratory Sciences, Alneelain University, Khartoum, Sudan \\ Email: *Nasralimohammed@yahoo.com
}

How to cite this paper: Ahmed, I.I., SirElfatouh, A.M. and Gaufri, N.E.A.M. (2016) Significant Reduction of Vitamin B12 Levels in Sudanese Sickle Cell Disease Patients. Open Access Library Journal, 3: e3208. http://dx.doi.org/10.4236/oalib.1103208

Received: November 6, 2016

Accepted: December 26, 2016

Published: December 29, 2016

Copyright $\odot 2016$ by authors and Open Access Library Inc.

This work is licensed under the Creative Commons Attribution International License (CC BY 4.0).

http://creativecommons.org/licenses/by/4.0/

\begin{abstract}
Background: Vitamin B12 (Cobalamin) one of the most important vitamins for its normal functioning to maintain the nerve system and for their role in production of DNA. Objective: This study was aimed to measure and assess the serum Cobalamin levels in Sudanese patients with Sickle-cell disease (SCD) and compared with those without Sickle-cell disease. Materials and Method: This is a case control study conducted in Sudan during March 2015. A total of 160 volunteers were enrolled in this study. 80 were known Sudanese patients professionally diagnosed with homozygous sickle cell; their age ranged from 6 months to 15 years as patients group. Further 80 normal healthy were as control group; their age and gender were similar to patient group. Serum was prepared from clotted blood samples. The Cobalamin concentrations were measured in both groups of SCD patients and in a normal healthy control group using Enzyme Linked Immune immunosorbent assay method (ELISA), Map lap Plus-Italy. For statistical analysis, the laboratory parameters were compared between the two groups and tested for statistical significance using Statistical package for social scent (SPSS) version 20. Result: In this study the mean of serum Cobalamin in the sickle cell patients was statistically significantly lower compared with the normal non-sickle cell disease group with $p$ value $=0.01$. Conclusion: $7.1 \%$ of Sudanese sickle cell disease has a deficient serum Cobalamin (hypocobalaminemia).
\end{abstract}

\section{Subject Areas}

Hematology

\section{Keywords}

Vitamin B12, Cobalamin, Sickle Cell Disease, Sudan

\section{Introduction}

Sickle-cell disease (SCD) is a group of genetically passed down blood disorders. The 
most common type is known as sickle-cell anaemia (SCA). It results in an abnormality in the oxygen-carrying protein haemoglobin found in red blood cells. This leads to a rigid, sickle-like shape under certain circumstances. Sickle-cell disease occurs when a person inherits two abnormal copies of the hemoglobin gene, one from each parent. [1]. One of the main problems of sickle-cell disease in children is the development of cerebrovascular disease and cognitive impairment, and the role of blood transfusion and hydroxycarbamide for prevention of these complications is starting to be understood. Recurrent episodes of vaso-occlusion and inflammation result in progressive damage to most organs, including the brain, kidneys, lungs, bones, and cardiovascular system, which become apparent with increasing age [2]. Cobalamin is a water-soluble vitamin that has a key role in the normal functioning of the brain and nervous system, and the formation of red blood cells. It is involved in the metabolism of every cell of the human body, especially affecting DNA synthesis, fatty acid and amino acid metabolism [3]. Vitamin B12 deficiency, also known as hypocobalaminemia, refers to low blood levels of vitamin B12 [4]. A wide variety of signs and symptoms may occur including a decreased ability to think and change in personality such as depression, irritability. Abnormal sensations, changes in reflexes, and poor muscle function can also occur as the most inflammation of the tongue, decreased taste, low red blood cells, reduced heart function, and decreased fertility [5]. In young children symptoms include poor growth, poor development, and difficulties with movement [6]. Without early treatment some of the changes may be permanent [7]. Also manifestations of Cobalamin deficiency include megaloblastic anemia and neuropsychiatric dysfunction. The prevalence of Cobalamin deficiency in the general population is variable depending on the age, population studied and the criteria for diagnosis [8] [9] [10]. The causes of deficiency include Inadequate dietary intake of vitamin B12 [11] [12] [13], Selective impaired absorption of vitamin B12 due to intrinsic factor deficiency, Impaired absorption of vitamin B12 in the setting of a more generalized malabsorption or maldigestion syndrome. Forms of achlorhydria (including that artificially induced by drugs such as proton pump inhibitors and histamine 2 receptor antagonists) can cause B12 malabsorption from foods, since acid is needed to split B12 from food proteins and salivary binding proteins. After surgical removal of the small bowel (for example in Crohn's disease), the patient presents with short bowel syndrome and is unable to absorb vitamin B12. This can be treated with regular injections of vitamin B12 [14]. Long-term use of ranitidine hydrochloride may contribute to deficiency of vitamin B12 [15]. Celiac disease may also cause impaired absorption of this vitamin, though this is due not to loss of intrinsic factor, but rather damage to the small bowel. In case of removal of part of the stomach, procedures such as the adjustable gastric band type do not appear to affect B12 metabolism significantly. Bacterial overgrowth in parts of the small bowel is thought to be able to absorb B12. An example occurs in so-called blind loop syndrome. The diabetes medication metformin such as metformin may interfere with B12 dietary absorption [16] and nitrous oxide misuse [17]. Cobalamin deficiency has often been defined as a 
serum Co-balamin concentration of less than $200 \mathrm{pg} / \mathrm{mL}$ (148 pmol/L) with limited sensitivity and specificity [18]. Subjects with sickle cell disease (SCD) may be at higher risk of Cobalamin deficiency because of increased demand, inadequate supply, coexisting folate deficiency or malabsorption [19]. Folic acid, one from treatment of sickle disease, if given particularly in large doses, can mask vitamin B12 deficiency by completely correcting haematological abnormalities. In vitamin B12 deficiency, folic acid can produce complete resolution of the characteristic megaloblastic anaemia, while allowing potentially irreversible neurological damage (from continued inactivity of methylmalonyl mutase) to progress. Thus, vitamin B12 status should be determined before folic acid is given as monotherapy [20]. More studies estimate vitamin B12 in patients with severe sickle cell anemia, some from which show significant deficiency in vitamin B12 [21] and other not [22] [23]. One study showed that there is no different of the mean of Cobalamin in patients with sickle disease and those without sickle disease [24]. In the present study, we compared serum Cobalamin concentrations between Sudanese with sickle cell disease SCD and compared with that non sickle cell disease.

\section{Materials and Method}

This is descriptive case control study done during March 2015 at Alneelain University, faculty of medical laboratory science, Khartoum, Sudan. A total of 160 subject were enrolled in this study $80(50 \%)$ male and (50\%) female were known Sudanese patients professionally diagnosed with homozygous sickle cell disease by hemoglobin electrophores is admitted to Jaffer ibnoof teaching hospital, Khartoum, Sudan; their age ranged from 6 month to 15 years as patients group. Further 80 normal healthy as normal control group; their age and gender were harmonized with patients group. The ethical approval was taken from the faculty of medical laboratory science; Alneelain University and the informed consent were taken before samples were collected from all participants in this study. Exclusion criteria of this study were included a previous known diagnosis of Cobalamin deficiency, current treatment with oral, intramuscular or subcutaneous Cobalamin, severe illness, or malnutrition as determined by a body mass index below 18.5. Subjects were recruited as SCD or as controls by medical history. In this study the Cobalamin concentrations were measured in both groups of SCD patients and in a normal healthy control group by using Enzyme Linked Immune immunosorbent assay (ELISA) method, Map lap Plus-Italy. For statistical analysis, the data were analyzed using SPSS version 20. T test was used to compare the serum cobalamin level between the two study group, and the level of significance was set to less than 0.05 .

\section{Result}

The current study revealed that the mean of serum Cobalamin in the sickle cell patients was statistically significantly lower compared with the normal non sickle cell disease group ( $p$ value 0.01 ) (Table 1 ).

The present study showed that $7.1 \%$ of Sudanese sickle cell disease patients have low-Cobalamin but no anyone has a neurological manifestation. 
Table 1. Correlation of serum Cobalamin in SCD patients and normal control group.

\begin{tabular}{rcc}
\hline Parameter & Mean \pm SD & P value \\
\hline Cobalamin pmol/L SCD patient 80 & $348.9 \pm 12.5$ & 0.01 \\
Normal control 80 & $629.9 \pm 37.1$ & \\
\hline
\end{tabular}

Based on the gender this study showed that there is no any statistically significantly different between male and female in SCD deficient serum Cobalamin patient with ( $\mathrm{p}$ value 0.62 ) (Table 2).

\section{Discussion}

Sickle cell anemia is an inherited blood disorder due to substitution of thyamine by adenine in glutamic acid which in turn results in the substitution of valine to glutamic acid in position number six in Beta globin chain, this will cause deoxygenated sickle haemoglobin to form polymers that ultimately destroy red blood cells [25]. In Sudan, sickle cell anaemia is the one of the major types of anaemia especially in western Sudan where the sickle cell gene is more frequent [26]. Vitamin B12 (Cobalamin) is a water-soluble vitamin that is crucial to normal neurologic function, red blood cell production, and DNA synthesis. It's very essential for three enzymatic processes: the conversion of homocysteine to methionine; the conversion of methylmalonic acid to succinyl coenzyme A; and the conversion of 5-methyltetrahydrofolate to tetrahydrofolate, a process necessary for DNA synthesis and red blood cell production [27]. The present study showed that the serum cobalamin is significantly lower in SCD patients compared with those normal non sickle cell disease groups with ( $\mathrm{p}$ value 0.01 ). These findings are in agreement with Osifo BO et al. in 1983 and 1984 respectively [19] [28]. The interesting findings of this study were advocate the previously data cited by Al-Momen et al. in 1995 who concluded that in Thirty-seven of the 85 patients (43.5\%) had serum vitamin B12 levels below normal values (mean $84.3 \pm 28.7$, range $7-145$ pmol. $\mathrm{L}^{-1}$ ) [21]. Our findings were consistent with Kamineni et al. in 2006 who conclude that $18.1 \%$ of African American with SCD had serum cobalamin defiance's [29]. The interesting finding of this study also in concordance with O. I. Ajayi et al. who published in 2013 that Cobalamin deficiency was present in $6.9 \%$ of SCD patients [30]. Inadequate dietary intake or increased the demand of cobalamin may be lead to the cobalamin deficiency in sickle cell patients; however others factor also might be has a role in cobalamin deficiency such as decreased cobalamin production by stomach or decreased absorption from the ileum due to the crisis of sickle cell disease [31] [32]. Based on the gender this study showed that no any statistically significantly different in SCD patient deficient serum Cobalamin ( $\mathrm{p}$ value 0.62 ). This finding was in concordance with study published in 2013 by O. I. Ajayi et al. who reported that there is no significant difference in median of (interquartile range) cobalamin concentration for all male and female subjects [30].

In this study there are two limitations, the sample size is small and narrowing the duration of the study. 
Table 2. Correlation of serum Cobalamin in SCD patients according to the gender.

\begin{tabular}{cccc}
\hline Parameter & SCD patient gender & Mean \pm SD & P value \\
\hline \multirow{2}{*}{ Cobalamin pmol/L } & Male & $372.1 \pm 32.5$ & 0.62 \\
& Female & $327.9 \pm 78.1$ & \\
\hline
\end{tabular}

\section{Conclusion}

The present study concluded that the $7.1 \%$ of Sudanese Sickle Cell Disease patients had lower serum cobalamin concentrations in comparison with non-Sickle Cell Disease patients. Moreover, the main cause of diminished serum cobalamin concentrations in SCD remains unclear.

\section{References}

[1] National Heart, Lungand Blood Institute (2016). http://www.nhlbi.nih.gov/health/health-topics/topics/sca.

[2] Rees, D.C., Williams, T.N. and Gladwin, M.T. (2010) Sickle Cell Disease. Lancet, 376, 20182031. https://doi.org/10.1016/S0140-6736(10)61029-X

[3] Yamada, K. (2013) Chapter 9. Cobalt: It's Role in Health and Disease. In: Sigel, A., Sigel, H. and Sigel, R.K.O., Eds., Interrelations between Essential Metal Ions and Human Diseases. Metal Ions in Life Sciences 13, Springer, Berlin, 295-320. https://doi.org/10.1007/978-94-007-7500-8 9

[4] Herrmann, W. (2011) Vitamins in the Prevention of Human Diseases. Walter de Gruyter, Berlin, 245.

[5] Hunt, A., Harrington, D. and Robinson, S. (2014) Vitamin B12 Deficiency. BMJ, 349, g5226. https://doi.org/10.1136/bmj.g5226

[6] National Institutes of Health: Office of Dietary Supplements (2016) Dietary Supplement Fact Sheet: Vitamin B12-Health Professional Fact Sheet.

[7] Lachner, C., Steinle, N.I. and Regenold, W.T. (2012) The Neuropsychiatry of Vitamin B12 Deficiency in Elderly Patients. The Journal of Neuropsychiatry and Clinical Neurosciences, 24, 5-15. https://doi.org/10.1176/appi.neuropsych.11020052

[8] McLean, E.D., Allen, L.H., Neumann, C.G., Peerson, J.M., Siekmann, J.H., Murphy, S.P., Bwibo, N.O. and Demment, M.W. (2007) Low Plasma Vitamin B-12 in Kenyan School Children Is Highly Prevalent and Improved by Supplemental Animal Source Foods. The Journal Nutrition, 137, 676-682.

[9] Pfeiffer, C.M., Caudill, S.P., Gunter, E.W., Osterloh, J. and Sampson, E.J. (2005) Biochemical Indicators of B Vitamin Status in the US Population after Folic Acid Fortification: Results from the National Health and Nutrition Examination Survey 1999-2000. The American Journal of Clinical Nutrition, 82, 442-450.

[10] Campbell, A.K., Miller, J.W., Green, R., Haan, M.N. and Allen, L.H. (2003) Plasma Vitamin B-12 Concentrations in an Elderly Latino Population Are Predicted by Serum Gastrin Concentrations and Crystalline Vitamin B-12 Intake. The Journal of Nutrition, 133, 27702776.

[11] Kittaka-Katsura, H., Fujita, T., Watanabe, F. and Nakano, Y. (2002) Purification and Characterization of a Corrinoid Compound from Chlorella Tablets as an Algal Health Food. Journal of Agricultural and Food Chemistry, 50, 4994-4997. https://doi.org/10.1021/jf020345w 
[12] Watanabe, F., Takenaka, S., Kittaka-Katsura, H., Ebara, S. and Miyamoto, E. (2002) Characterization and Bioavailability of Vitamin B12-Compounds from Edible Algae. Journal of Nutritional Science and Vitaminology, 48, 325-231. https://doi.org/10.3177/jnsv.48.325

[13] Nakano, S., Takekoshi, H. and Nakano, M. (2010) Chlorella Pyrenoidosa Supplementation Reduces the Risk of Anemia, Proteinuria and Edema in Pregnant Women. Plant Foods for Human Nutrition, 65, 25-30. https://doi.org/10.1007/s11130-009-0145-9

[14] Lam, J.R., Schneider, J.L., Zhao, W. and Corley, D.A. (2013) Proton Pump Inhibitor and Histamine 2 Receptor Antagonist Use and Vitamin B12 Deficiency. JAMA, 310, 2435-2442. https://doi.org/10.1001/jama.2013.280490

[15] Yeomans, N.D., Hanson, R.G., Smallwood, R.A., Mihaly, G.W. and Louis, W.J. (1982) Effect of Chronic Ranitidine Treatment on Secretion of Intrinsic Factor. BMJ, 285, 264. https://doi.org/10.1136/bmj.285.6337.264

[16] Ting, R.Z., Szeto, C.C., Chan, M.H., Ma, K.K. and Chow, K.M. (2006) Risk Factors of Vitamin B(12) Deficiency in Patients Receiving Metformin. Archives of Internal Medicine, 166, 1975-1979. https://doi.org/10.1001/archinte.166.18.1975

[17] Kondo, H., Osborne, M.L., Kolhouse, J.F., Binder, M.J., Podell, E.R., Utley, C.S., Abrams, R.S. and Allen, R.H. (1981) Nitrous Oxide Has Multiple Deleterious Effects on Cobalamin Metabolism and Causes Decreases in Activities of Both Mammalian Cobalamin-Dependent Enzymes in Rats. The Journal of Clinical Investigation, 67, 1270-1283. https://doi.org/10.1172/JCI110155

[18] Schneede, J. and Ueland, P.M. (2005) Novel and Established Markers of Cobalamin Deficiency: Complementary or Exclusive Diagnostic Strategies. Seminars in Vascular Medicine, 5, 140-155. https://doi.org/10.1055/s-2005-872399

[19] Osifo, B.O., Adeyokunnu, A., Parmentier, Y., Gerard, P. and Nicolas, J.P. (1983) Abnormalities of Serum Transcobalamins in Sickle Cell Disease (HbSS) in Black Africa. Scandinavian Journal of Hematology, 30, 135-140. https://doi.org/10.1111/j.1600-0609.1983.tb01459.x

[20] Victorherbert.com. Argument for Providing B12 with Food Fortification of Folate, Since Otherwise Folate Will Correct Hematological Symptoms While Leaving Neurological Symptoms to Progress.

[21] Al-Momen, A.K. (1995) Diminished Vitamin B12 Levels in Patients with Severe Sickle Cell Disease. Journal of Internal Medicine, 237, 551-555. https://doi.org/10.1111/j.1365-2796.1995.tb00884.x

[22] Segal, J.B., Miller, E.R., Brereton, N.H. and Resar, L.M. (2004) Concentrations of B Vitamins and Homocysteine in Children with Sickle Cell Anemia. Southern Medical Journal, 97, 149-155. https://doi.org/10.1097/01.SMJ.0000051740.56511.93

[23] Lowenthal, E.A., Mayo, M.S., Cornwell, P.E. and Thornley-Brown, D. (2000) Homocysteine Elevation in Sickle Cell Disease. Journal of the American College of Nutrition, 19, 608-612. https://doi.org/10.1080/07315724.2000.10718958

[24] van der Dijs, F.P., Schnog, J.J., Brouwer, D.A., Velvis, H.J., van den Berg, G.A., Bakker, A.J., Duits, A.J., Muskiet, F.D. and Muskiet, F.A. (1998) Elevated Homocysteine Levels Indicate Suboptimal Folate Status in Pediatric Sickle Cell Patients. American Journal of Hematology, 59, 192-198. https://doi.org/10.1002/(SICI)1096-8652(199811)59:3<192::AID-AJH3>3.0.CO;2-8

[25] Beutler, E., Lichtman, M.A., Coller, B.S., Kipps, T.J. and Williams, U. Hematology. 6th Edition, Churchill Livingstone, London, 469.

[26] Mohammed, A.O., Attalla, B., Bashir, F., Ahmed, F.E., Elhassan GafarIbnauf, A., et al. 
(2006) Relation of Sickle Cell Gene to the Ethnic and Geographic Groups Populating the Sudan. Public Health Genomics, 9, 113-120. https://doi.org/10.1159/000091489

[27] Evatt, M.L., Mersereau, P.W., Bobo, J.K., Kimmons, J. and Williams, J. Why Vitamin B12 deficiency Should Be on Your Radar Screen. Centers for Disease Control and Prevention. http://www.cdc.gov/ncbddd/b12/index.html

[28] Lukanmbi, F.A. and Adeyokunnu, A. (1984) Serum Cobalamin Concentration in Sickle Cell Disease (HbSS). Acta Haematologica, 71, 299-303.

[29] Kamineni, P., Chirla, S., Dinh, K., et al. (2006) Low Cobalamin Levels in African Americans with and without Sickle Cell Disease. Journal of the National Medical Association, 98, 352356.

[30] Ajay, O.I., Bwayo-Weaver, S., Chirla, S., Serlemitsos-Day, M., Daniel, M., et al. (2013) Cobalamin Status in Sickle Cell Disease. International Journal of Laboratory Hematology, 35, 31-37. https://doi.org/10.1111/j.1751-553X.2012.01457.x

[31] Sinow, R.M., Johnson, C.S., Karnaze, D.S., Siegel, M.E. and Carmel, R. (1987) Unsuspected Pernicious Anemia in a Patient with Sickle Cell Disease Receiving Routine Folate Supplementation. Archives of Internal Medicine, 147, 1828-1829.

https://doi.org/10.1001/archinte.1987.00370100142023

[32] Dhiman, R.K., Yusif, R.A., Nabar, U.J. and Albaqali, A. (2004) Gastrointestinal: Ischemic Enteritis and Sickle Cell Disease. Journal of Gastroenterology and Hepatology, 19, 1318. https://doi.org/10.1111/j.1440-1746.2004.03630.x

\section{Submit or recommend next manuscript to OALib Journal and we will provide best} service for you:

- Publication frequency: Monthly

- 9 subject areas of science, technology and medicine

- Fair and rigorous peer-review system

- Fast publication process

- Article promotion in various social networking sites (LinkedIn, Facebook, Twitter, etc.)

- Maximum dissemination of your research work

Submit Your Paper Online: Click Here to Submit

Or Contact service@oalib.com 